\title{
Portfolio-Based Learning Models on Students' Collaborative Ability
}

\author{
Nurhaedah ${ }^{1}$, Nur Abidah Idrus ${ }^{2}$, St. Nursiah ${ }^{3}$, Abdul Rahman $^{4}$ \\ $\underline{\text { nurhaedahrahman@yahoo.co.id }}^{1}$, $\underline{\text { nurabidahidrus@gmail.com }}^{2}, \underline{\text { abdulrahmannompo@yahoo.com }}^{4}$ \} \\ ${ }^{1,2,3}$ Primary Teacher Education, Faculty of Education, Universitas Negeri Makassar, Makassar, \\ Indonesia \\ ${ }^{4}$ Junior High School 37 Makassar, Makassar, Indonesia ${ }^{4}$
}

\begin{abstract}
This study examines the influence of portfolio-based learning models on student cooperative ability. The purpose of this study is to describe students' cooperative ability by using portfolio-based learning models. The research method used intact group comparison. The data analysis technique used is the analysis of Descriptive Statistics and Inferential Statistical Analysis. The results of this study indicated that the cooperative ability of students in the experimental group was in the moderate category, while in the control group was in a very low category. The results t-test, post-test scores in the experimental group and the control group showed the results of Sig. (2-tailed) $<0.05$, which means that there is an effect of portfolio-based learning models on the students' cooperative ability. Thus, portfolio-based learning models can influence the ability of student collaboration of fifth grade students SD Lariang Bangi II Makassar
\end{abstract}

Keywords: portfolio-based learning model, collaborative ability.

\section{Introduction}

Cooperative ability is important in people's lives especially democratic culture and becomes one of the five indicators of social behavior, namely responsibility, caring for others, being open, and creativity (Wulandari, Arifin, \& Irmawati, 2015). Cooperation emphasizes efforts to build knowledge and skills through students' teamwork activity (Pratiwi, 2015). In addition, the ability to cooperate can increase both self-confidence and interactional ability as well as train students to adapt to new environments (Yulianti, Djatmika, \& Susanto, 2016). Specifically in the learning process, students' cooperation enables them to achieve predetermined learning goals. This is because by developing a collaborative culture in the learning process, students are easier to achieve learning goals and to live life in this digital age (Shamir Inbal \& Blau, 2016)

The cooperative ability at schools needs to be improved, knowing that the learning process still uses the absolutism paradigm, namely the process starting from designing learning activities, teaching, learning, and conducting evaluations that flow linearly. Teachers are more active than students who are considered as passive recipients of knowledge. Students merely come to school to sit, listen, take notes, repeat at home and memorize for test. Learning like this makes students passive because students are in a boring routine so the learning is less interesting (Kurnianita, n.d.).

The ability to cooperate is one character that must be instilled as early as possible (Yulianti et al., 2016). Furthermore, it was stated that cooperation is a group activity to work 
on or complete a task together, in this cooperation, there is usually interaction between group members who have the same goal to be achieved together.

The fact shows that the cooperative ability at schools is still low. This happens because of the lack of early socialization and cooperative behaviors (Wulandari et al., 2015). One example is that there are still students who do not want to help their friends and there are some students who are embarrassed because they are considered weak if they ask for help from friends (Pratiwi, 2015). In addition, the learning system that is applied is still teacher centered, so the ability of student to cooperate will not appear in learning activities. Supposedly, if you expect the good quality of education, learning can be realized with learning models (Nurfitasari \& Suryandari, n.d.).

Varied learning will create a meaningful and enjoyable learning environment for students (Taniredja, 2012). Based on this, determining the right model greatly helps learning process run smoothly. The learning model has a considerable role in teaching and learning activities. Learning objectives will be achieved by using the right learning model, in accordance with the standards of success that have been set in a goal. The portfolio-based learning model is one of the right steps, because it can revive the learning atmosphere (Sadikin, Aina, \& Hakim, 2016).

"The portfolio-based learning model is a learning innovation designed to help students understand the material that is studied in class" (Taniredja, 2012). This portfolio-based learning model is a learning model that will help students better understand the meaning of cooperation (Zahra, Tandi, \& Ratna, n.d.). One of the advantages of portfolio-based learning models encourages collaboration (communication and relationships) between students students and students-teachers. The learning experiences will be stored in their long term memories because they have carried out a series of learning processes from knowing, understanding themselves, doing activities and learning to cooperate with others in society (Muhson, 2011).

Furthermore, it was stated that the portfolio-based learning model is one of the innovation results in the learning model based on the Four Pillars of Education, namely, learning to know, learning to do, leraning to live together and learning to be someone. Learning to live together means that students is able to participate and cooperate with others (Taniredja, 2012). Collaboration will arise through group learning. Group learning can encourage students to be more active by making variations in groups, the goal is to increase the activities of each in the group, to train problem solving, to make decisions, and to develop creative ideas (Kurnianita, n.d.). The steps of the portfolio-based learning model used in this study are 1) identifying problems; 2) choosing problems to study in class; 3) reviewing problems in class; 4) Developing class portfolio; 5) Conducting portfolio presentation and 6) Reflecting on learning experiences (Taniredja, 2012).

Eggen and Kauchak in Apriono (Pratiwi, Ardianti, \& Kanzunnudin, 2018) suggest that in learning activities, there are aspects of cooperative abilities that can be used, namely: (1) politely listening and taking the speaking turn after the other person has finished talking, (2) interrupting politely, (3) respecting other people's ideas, (4) apprehending other people's ideas before expressing disagreement, and (5) supporting each group members' participation. Other indicators of cooperative ability are group discussion, group participation, and acceptance of responsibility and other people's opinions (Julita, 2016).

Based on the explanation above, this study examines the effect of Portfolio-Based learning models on the cooperative ability of students in Lariang Bangi II Elementary School, Makassar District, Makassar City. 


\section{Method}

This study uses the Intact-Group Comparison research design. The population in this study was all students of Lariang Bangi II Elementary School, Makassar District, Makassar City. The total population is 118 students. The sampling technique used was non probability sampling techniques. As the samples in this study were the fifth grade students of Lariang Bangi II Elementary School in Makassar District, Makassar City, clearly the sampling used was Purposive Sampling, namely the technique of determining the sample with a specific purpose / reason. Data collection techniques are observations to see the ability of student collaboration and documentation. The data analysis technique used is the analysis of Descriptive Statistics and Inferential Statistical Analysis. Hypothesis testing is done to find out whether the portfolio-based learning model influences the cooperative ability of fifth grade students of Lariang Bangi II Elementary School Makassar District Makassar City with IBM SPSS software version 22.0. The hypothesis test used was independent sample t-test, which is first tested for normality using the Kolmogorov Smirnov Normality Test.

\section{Results and Discussion}

The research was carried out in class V of Lariang Bangi II Elementary School in Makassar District, Makassar City. The treatment given is the implementation of learning using portfolio-based learning model. The cooperative ability is score of the observation results by observing when students working in groups to make portfolios with themes "around us". The observations are carried out during two meetings by applying a portfolio-based learning model. This study was conducted in 4 meetings, 2 times in experimental class and 2 times in control class. The researcher conducted a study with the use of a portfolio-based learning model for fifth grade students of Lariang Bangi II Elementary School, Makassar District, Makassar City, which was used as the object of the research.

In the first meeting, the researcher gave the first treatment in $3 \times 35$ minutes by giving teaching material about pure substance and a mixture. The researcher then gave an apperception before discussing the material. The researcher briefly explained about pure substances and tested the students' initial knowledge about the learning material, the next step students worked on student worksheets in groups relating to a single mixture of substances. During the group discussion process, each observer observed students' activities with the use of observation checklist containing indicators met by each student. The indicators of cooperation were group discussion, group participation, and acceptance of responsibility and other people's opinions.

During observations, students discussed and payed attention to events that occur in observations of pure substance and a mixture. Conclusions were obtained after the researcher invited students to discuss the right answers regarding the material and worksheets given.

In the second meeting, the researcher continued the teaching topic on advertising. Students were asked to make observations by listening to the researchers' explanations first. The researchers tested the students' initial knowledge about the material and linked it with daily life. Then the students work on students' worksheet in groups. Similar to the first meeting during the group discussion process, each observer observed the students' activities and gave observations in the form of an observation checklist on indicators that were met by 
each student. In the final phase the students work on the final questions in the lesson for 20 minutes.

Recapitulation of the observation results on students' cooperative ability can be seen in the following table

Table 1. Distribution, frequency and percentage of the category of cooperative abilities of

\begin{tabular}{llll}
\hline & \multicolumn{2}{c}{ the experimental group } \\
\hline Interval & Category & Frequency & Percentage \\
& & & $0 \%$ \\
\hline $88,34<(\mathrm{X}) \leq 100$ & High & 0 & $75,0 \%$ \\
\hline $66,67<(\mathrm{X}) \leq 88,34$ & Moderate & 9 & $16,7 \%$ \\
\hline $50<(\mathrm{X}) \leq 66,67$ & Low & 2 & $8,3 \%$ \\
\hline $33,33 \leq(\mathrm{X}) \leq 50$ & Very low & 1 & $100 \%$ \\
\hline Total & & 12 & \\
\hline
\end{tabular}

Based on Table 1 above, it can be seen that the coperation between students in experimental class was categorized to be moderate in the percentage of $75.0 \%$ with a frequency of 9 people. From these data, there were no students who gain the ability to cooperate in the high category. There was 1 student who was in the very low category with a percentage of $8.3 \%, 2$ students were in the low category with a percentage of $16.7 \%$.

Table 2. Distribution, frequency and percentage of the category of Cooperative ability of the control class students.

\begin{tabular}{llll}
\hline Score Interval & Category & Frequency & Percentage \\
\hline $88,34<(\mathrm{X}) \leq 100$ & High & 0. & $0 \%$ \\
\hline $66,67<(\mathrm{X}) \leq 88,34$ & Moderate & 0 & $0 \%$ \\
\hline $50<(\mathrm{X}) \leq 66,67$ & Low & 5 & $41,7 \%$ \\
\hline $33,33 \leq(\mathrm{X}) \leq 50$ & Very low & 7 & $58,3 \%$ \\
\hline Jumlah & & 12 & $100 \%$ \\
\hline & & &
\end{tabular}

The data results of frequency and percentage categories in table 2 above show that the cooperative ability of the control group was in the very low category with a percentage of 58.3 $0 \%$ with a frequency of 7 people. From these data there were no students who obtained cooperative skills in the high category and the moderate category. There were 5 students in the low category with a percentage of $51.7 \%$.

Furthermore, the results of the normality test are presented to find out whether the data taken are normally distributed or not. The normality test data were obtained from the posttest results of students' cooperative ability. The normality test was carried out with the help of the SPSS version 20.0 program with the Kolmogorov Smirnov Normality Test. The data were said to be normally distributed if Asymp Sig. (2-tailed) greater than 0.05. The following are the results of the posttest data normality test.

Table 3. Normality Test Results of the posttest data of the experimental group and the control

Tests of Normality

$$
\text { group }
$$

Kolmogorov-Smirnov $^{\text {a }} \quad$ Shapiro-Wilk




\begin{tabular}{lllllll} 
& Statistic & Df & Sig. & Statistic & Df & Sig. \\
\hline Experiment &, 169 & 12 &, $200^{*}$ &, 898 & 12 &, 150 \\
\hline Control &, 222 & 12 &, 106 &, 926 & 12 &, 338 \\
\hline
\end{tabular}

Table 3 above is the result of a normality test with Kolmogrov-Smirnov. The table above shows that the data of cooperative ability of students in the experimental group and the control group are normally distributed. This is based on the normality test of the data obtained for the experimental group $0.200>0.005$ and in the control group $0.106>0.005$. Thus it can be concluded that the distribution of data is normally distributed.

Testing the hypothesis in this study using t-test, namely independent samples t-test. Analysis of the independent sample t-test was used to compare or find out the average differences of the two independent data sample groups. The results of independent sample t-test are presented as follows:

Table 4. Results of Independent Sample T-Test values for the pretest of the experimental class and the control class.

\begin{tabular}{|l|l|l|l|l|}
\hline Data & T & Df & $\begin{array}{l}\text { Sig.(2- } \\
\text { tailed })\end{array}$ & Description \\
\hline Posttest Experimental Class and & 6,448 & 22 & 0,000 & $0,000<0,05$ \\
Posttest Control Class & & & \\
\hline
\end{tabular}

Based on the table above, p-value sig (2-tailed) is 0,000 which is smaller than 0.05 so Ho is rejected and $\mathrm{H} 1$ is accepted. These results indicate that there is a significant difference in the cooperative ability of fifth grade students who were taught using a portfolio-based learning model and the average cooperative ability of the group was higher or in this case better than the control group taught using conventional learning. So it can be concluded that the experimental group taught using a portfolio-based learning model had an effect on the cooperative ability of fifth grade students of Lariang Bangi II Elementary School, Makassar District, Makassar City.

The results of the research show that the learning conducted using a portfolio-based learning model increases the cooperative ability of students with the observed indicators of group discussion, group participation, and acceptance of responsibility and other people's opinions compared to the groups of students who were not given treatment in the portfolio learning model. The control group's cooperative ability was in the very weak category while experimental group' cooperative ability was in the moderate category. This is in line with the theory that the portfolio-based learning model can encourage collaboration such as communication and relations between students-students and students-teachers, learning experiences stored in memory will last longer because they have carried out a series of learning processes from knowing, understanding themselves, carry out activities and learn to cooperate with their colleagues to live together in the community (Yulianti et al., 2016). 
The portfolio-based learning model actively requires students in learning activities. Student activity is measured by the initial step of identifying problems. Student learning activities combine cognitive, affective and psychomotor. The student learning portfolio model identifies problems and relates them to daily life in a realistic way. This activity encourages all senses and develops students' knowledge and character (Kurnianita, n.d.). Furthermore, it was stated (Zahra et al., N.d.) that the portfolio-based learning model is a learning innovation that helps students understand and develop the learning materials studied in class that emphasize student creativity and gain meaningful learning experiences through information obtained and then collect it in a report. Thus the portfolio-based learning model effectively enhances student cooperative ability.

\section{Conclusion}

Based on the results of data analysis and discussion, it can be concluded that the results of the study are as follows:

1. Students' cooperative ability taught using the portfolio-based learning model is in the moderate category, while the cooperative ability of students who were not taught using the portfolio learning model is in the very low category.

2. There is the effect of applying portfolio-based learning model to the cooperative ability of students. This is evidenced by the difference in the average value of cooperative ability between class $\mathrm{V}$ in the experimental group and class $\mathrm{V}$ in the control group, which is $68.41>48.61$ with p-value sig. ( 2 tailed) of $0.00<0,05$ means that the results after the treatment in the experimental group show that there is a significant effect of the portfoliobased learning model on the cooperative ability of students in Laring Bani II Elementary School, Makassar District, Makassar City.

\section{References}

[1] Dell'Olio, D. J. M. M., \& Donk, D. T. (2007). Models of Teaching: Connecting Student Learning with Standards. Thousand Oaks: SAGE Publications. Retrieved from http://public.eblib.com/choice/publicfullrecord.aspx?p=996882

[2] Kurnianita, E. (n.d.). Upaya Meningkatkan Kemampuan Kerjasama, Keaktifan Dan Hasil Belajar Siswa Menggunakan Model Cooperative Learning Tipe Co-Op Co-Op Pada Mata Pelajaran Ips Siswa Kelas VIII G SMP Negeri 1 Minggir Sleman, 16.

[3] Muhson, A. (2011). Portofolio-Based Instruction Sebagai Model Pembelajaran, 8, 11. Nurfitasari, Y., \& Suryandari, K. C. (n.d.). Analisis Kemampuan Kerjasama Siswa Dalam Pembelajaran Ipa (Studi Deskriptif Pada Siswa Kelas V Sd Negeri 4 Kutosari Tahun Ajaran 2017/2018), 7.

[4] Pratiwi, I. A. (2015). Pengembangan Model Kolaborasi Jigsaw Role Playing Sebagai Upaya Peningkatan Kemampuan Bekerjasama Siswa Kelas V SD Pada Pelajaran IPS. JURNAL KONSELING GUSJIGANG, 1(2). https://doi.org/10.24176/jkg.v1i2.411

[5] Pratiwi, I. A., Ardianti, S. D., \& Kanzunnudin, M. (2018). Peningkatan Kemampuan Kerjasama Melalui Model Project Based Learning (Pjbl) Berbantuan Metode Edutainment Pada Mata Pelajaran Ilmu Pengetahuan Sosial. Refleksi Edukatika: Jurnal Ilmiah Kependidikan, 8(2). https://doi.org/10.24176/re.v8i2.2357

[6] Sadikin, A., Aina, M., \& Hakim, N. (2016). Penerapan Asesmen Berbasis Portofolio Dan Jurnal Belajar Untuk Meningkatkan Kemampuan Metakognitif Dan Motivasi Belajar Mahasiswa Pada Mata Kuliah Perencanaan Pengajaran Biologi, 12. 
[7] Shamir Inbal, T., \& Blau, I. (2016). Digital Literacy Skills And The Challenge Of Collaborative Culture In Higher Education: From Individual Psychological Ownership To Co-Ownership (pp. 9012-9013). Presented at the International Conference on Education and New Learning Technologies, Barcelona, Spain. https://doi.org/10.21125/edulearn.2016.0096

[8] Taniredja, T. (2012). Model-Model Pembelajaran Inovatif. Bandung: Alfabeta. Wulandari, B., Arifin, F., \& Irmawati, D. (2015). Peningkatan Kemampuan Kerjasama dalam Tim Melalui Pembelajaran Berbasis Lesson Study. Jurnal Electronics, Informatics, and Vocational Education (ELINVO), 1, 8.

[9] Yulianti, S. D., Djatmika, E. T., \& Susanto, A. (2016). Pendidikan Karakter Kerja Sama Dalam Pembelajaran Siswa Sekolah Dasar Pada Kurikulum 2013. Jurnal Teori dan Praksis Pembelajaran IPS, $\quad$ 1(1), 33-38. https://doi.org/10.17977/um022v1i12016p033

[10] Zahra, S., Tandi, H. Y., \& Ratna, Y. (n.d.). Pengaruh Model Pembelajaran Berbasis Portofolio Terhadap Hasil Belajar Siswa Kelas V Pada Mata Pelajaran IPA SDN No 3 Parigi. Elementary School of Education E-Journal 8, 8(1), 1-15. 